\title{
Shifting from Ideal to Critical Multiculturalism in Canadian Teacher Education Programs:Examining the Challenges
}

\author{
Dragana Martinovic, Sheila Windle, and S. Nombuso Dlamini \\ (University of Windsor)
}

\begin{abstract}
This paper describes a recent initiative designed to provide support for teacher candidates from culturally diverse backgrounds as they traverse a one-year teacher education program in Canada. Results and discussion are based on qualitative data from an information survey, student-professor conversations, a review of seminar documents and processes, and observations and reflections made by professors conducting the seminar. Overall, the Language and Cultural Engagement Seminar was successful in providing a supportive environment in which complicated and politically volatile issues, which would otherwise have remained unacknowledged, were discussed openly. The main concerns expressed by participants were the communication concern (grammar, vocabulary, pronunciation, accent, etc.), concern for power and authority in the classroom, and the socio-cultural acceptance concern. Power and communication concerns diminished when teacher candidates felt a level of cultural acceptance in the classroom; therefore, we propose that socio-cultural acceptance be investigated in future research into the concern construct. Since differential pronunciation had the effect of positioning teacher candidates on the periphery of classroom discourse, we concluded that acceptance of accent diversity (lack thereof) was one barrier between ideal (policy) and experienced (lived) multi-cultures.
\end{abstract}

\section{Résumé}

Cet article décrit une initiative récente désignée à procurer un soutien aux étudiants-maîtres provenant de divers milieux socio-culturels pendant l'année de leur formation au Canada. Les résultats et les discussions sont basés sur les données qualitatives obtenues d'une surveillance de renseignements, des conversations entre professeurs et étudiants, une revision des documents et processus obtenus pendant un colloque et des observations et réflexions faites par les professeurs conduisant ce colloque. En général le colloque "Language and Cultural Engagement Seminar" a réussi à offrir un mileu positif dans lequel des problèmes compliqués ou explosifs, qui auraient pu passer inapperçus, avaient été discutés franchement. Les principales inquiétudes citées par les participants sont: l'inquiétude sur la communication (grammaire, vocabulaire, prononciation, accent, etc.), l'inquiétude concernant l'autorité et le pouvoir en classe. et l'inquiétude de n'être pas acceptés à cause de leurs antécédents socio-culturels. Mais les inquiétudes sur le pouvoir et la communication sont diminuées quand les étudiants-maîtres sentaient qu'ils atteignaient un certain niveau d'acceptation culturelle en classe. Nous proposons que l'acceptation socio-culturelle deviendra 
un sujet de recherche plus poussé dans l'avenir. Comme la prononciation différentielle avait l'effet de placer les instituteurs aux périphéries du discours en classe, nous avions conclu que l'acceptation des accents divers (ou le manque de) est une barrière entre l'idéal (politique) et l'expérience (vécue) d'un milieu à cultures multiples.

\section{Introduction}

Research indicates that because of immigration and other factors, over the past decade, the Canadian student population has become more culturally and linguistically diversified (James, 2004; Statistics Canada, 2004, 2005). Such student diversity however does not correspond with the make up of the teaching population. Critical education theorists suggest that diverse classes - classes that work in, and in between two or more languages and cultures to create students and teachers as engaged brokers, investigators, participants and producers of culture, language and identity - would provide a more complex, rich and politically sensitive learning experience. Yet, information from many education programs across the country also indicates that the learning experiences, and more specifically, the teaching practice experiences of those teacher candidates whose home culture and language (or variety of English) are at odds with the Canadian school literacy practices, are fraught with tensions, frustrations and challenges as they negotiate their classrooms and their teacher identities.

In a paper presented at the OTF/OADE Conference, Solomon (2004) speaks of the importance of engaging teacher candidates "in the exploration of their own identity formation and its potential impact on the pedagogical process" (p. 14). According to Solomon, this engagement is important because in an emergent socially and culturally diverse Canada, schooling is similarly becoming diverse; however, within schools there exists a tendency towards own-group cleavage, "racial homophily" and "ethnic encapsulation." Solomon then asks the question of how teacher education may reverse this tendency and create environments that allow candidates to engage each other across racial and cultural boundaries. In this paper we document our efforts towards the creation of such an environment and we present practices that act as barriers and enhancers towards this environment. We argue that as long as such an environment is viewed as beneficial only to candidates from minority groups, with little or no value to mainstream Canadians, ethnic encapsulation and own-group cleavage will continue to dominate Canadian schools, despite diversity.

There is paucity of literature examining the experiences of candidates from culturally diverse backgrounds as they go through teacher education programs and of literature that documents these experiences within recent initiatives designed to recruit and foster positive enriching learning journeys for these candidates. Exceptions in the Canadian context include the work of Myles, Cheng and Wang (2006). In the absence of a wide base of studies specific to this population within the teacher education field, we ground our arguments on the literature that sanctions the value of recruiting into the teaching population

16 Canadian and International Education Vol. 36 no.1 -June 2007 
teachers from diverse cultural and linguistic backgrounds. This grounding is cognizant of the complexities associated with presenting teachers from culturally diverse backgrounds as role models and solutions to students' disengagement and failure in schools. We agree with James's (2001) telling example that Black teachers are not:

uncritically accepted as the alternative. We are scrutinized, tested, and evaluated for the extent to which we 'ignore' or 'affirm' Black students or 'take the place of the colonizer.' The teachers from diverse but similar backgrounds as students can appear 'too harsh' and having 'unreasonable [higher] expectations' of diverse students, which may lead into conflicting situations and further student alienations. (p.162)

Our grounding is also cognizant of the challenges that teachers from minority groups face in dealing with issues of language and power in their classrooms (Dlamini, 2002; Myles et al., 2006). Nonetheless, we agree with New and Sleeter (1993), Ladson-Billings (1994), Carr (1995), Dei (2000), and others when asserting that by becoming part of the teaching population, teachers from diverse cultural and linguistic backgrounds can contribute positively to equity in education through enhancing cultural compatibility, demystifying the hidden curriculum, developing positive attitudes toward persons from a variety of backgrounds, expressing lived experiences, connecting with the students, and connecting with communities. Our examination then is designed to extend this literature through describing the processes that teacher candidates go through while learning to be teachers. We also present steps that we consider as fundamentally vital for enhancing the learning experiences of these candidates, consequently making teacher education programs attractive and therefore worthy of pursuit.

The discussion presented in this paper is based on results of an information survey conducted with teacher candidates at the end of their teacher education program, student-professor personal conversations, review of seminar documents and processes, as well as our observations and reflections from conducting the seminar. The discussion is also infused with "thick descriptions" (Geertz, 1973) of what Martinovic and Dlamini have experienced as immigrant women and as internationally educated women for whom English is an additional language.

By using our experiences as part of the discussion in this paper we are following current research practices in critical ethnography in which the position of the researcher as an embodied self is considered an important and valuable source (see, for example, Krenske, 2002). In addition, our experiences as integral parts of the discussion need to be understood within the framework of social identities that acknowledges the importance of bodies (women, Black and Slavic) as resources that are often tapped by "others" to enhance their understanding of issues considered typical of our cultural/racial backgrounds. A third, Canadianborn female professor, Sheila Windle joined the teaching team in the third year of the Language and Cultural Engagement seminar to offer support in the language component of the seminar. Having taught abroad, she brought yet another 
dimension of international teaching experience to the seminar, analysis of the survey, as well as to the writing of this piece. Important in this seminar were her understanding of and emphases on teaching language in context (Brady \& Shinohara, 2000; Commins \& Marimontes, 2006; Kramsch, 1998; Peregoy \& Boyle, 2005). Thus, what is offered in this paper is partly informed by these combined experiences of the instructors' efforts to help each student understand and analyze some of his/her teaching experiences and how these experiences are intertwined with personal socio-cultural and political locations.

\section{Diversity for Whom and by Whom}

Why Diversify?

The value placed on diversifying the teaching population has been slow to realize partly because of the small number of individuals from minority groups who choose to enter teacher education programs. Those who do enter are reported to commonly encounter segregation or repetition of the minority experiences characterizing their earlier schooling (Gordon, Aldrich, \& Dean, 1991). On the one hand, many teacher education programs now espouse principles of diversity, equity and social justice, all principles that are partly intended to attract and engage teacher candidates from diverse cultural and linguistic backgrounds. On the other hand, however, many of these programs are still notoriously known for the heavy reliance they place on traditional instruction techniques, on failing to academically engage candidates from minority groups, and on failing to prepare teacher candidates to meet the various realities, especially cultural and linguistic realities, they will encounter in schools (Ghosh, 2002; Myles et al., 2006). Moreover, Banks (2001) argues that it is the responsibility of teacher educators to guide candidates of mainstream backgrounds away from the problematic "colorblind attitude," which is premised on the simplistic notion that all students are "the same," thus undermining the diversity of their backgrounds. He states that it is difficult for mainstream students to recognize the role of ethnicity in education and understand how racism is institutionalized in schools. All these factors explain the small number of teacher candidates from minority groups in the teacher education programs.

There is extensive literature that identifies the range of diversity/differences that needs to be addressed within educational institutions. Similarly, over the years, though lacking any systematic account of the principles that ground the discursive framing, this literature also presents the rationale for and strategies towards dealing with these forms of diversity in schools. In the past decade literature examining diversity in schools has mainly focused on linguistic and cultural diversity that can be said to result from globalization and migration trends. In North America, the direction has been that many immigrants arrive from developing countries possessing diverse cultural, linguistic, and economic experiences and practices which require distinctly different educational approaches. In Canada, for example, the proportion of immigrants from Europe has decreased, and the greatest proportion now comes from Asia and the Middle East, with a significant number coming from South and Central America and the

18 Canadian and International Education Vol. 36 no.1 -June 2007 
Caribbean, as well as from Africa. While many of these new immigrants are allophones and are from visible minority groups, it is projected that by 2017, approximately $20 \%$ of Canadians will be visible minorities, with much higher concentrations of visible minorities in the largest centers (Canadian Heritage, Government of Canada, 2005). This literature on diversity in education suggests that the changes in migration trends need to be coupled with changes in the school systems' strategies to meaningfully embrace and engage the learning styles of students from culturally and linguistically diverse backgrounds - an area that has been a challenge for many years.

One of the challenges faced by schools is addressing the imbalance between the make up of the student population with that of teachers. Literature reveals that even though schools and classrooms present a wide range of cultural and linguistic diversity, the teaching force in the United States consists mainly of middle-class and monolingual European American females (Ladson-Billings, 1994; Sleeter, 2001; Villegas \& Lucas, 2002). Though little recent statistical data exist, anecdotal information also suggests that similar trends exist in Canadian schools, giving immediacy to Carr's 1995 report that in Toronto, Canada's most diverse city, where almost $50 \%$ of secondary school students were racial minorities, only $10 \%$ of teachers were such.

Literature also indicates that the increasing heterogeneity in classrooms parallels increasing school failure among culturally and linguistically diverse students (Fueyo \& Bechtol, 1999). Such deductions make relevant the argument that schools need teachers who possess knowledge of the subject matter, how to teach, as well as an understanding of the diversity present in classrooms (CochranSmith, 1997; Commins \& Marimontes, 2006; Garcia, 1991; Grant, 1997; LadsonBillings, 1994; Nieto, 1992; Sleeter, 2001; Villegas \& Lucas, 2002; Zeichner, 1993; Zeichner \& Melnick, 1996). Teachers who have an understanding and appreciation of cultural and linguistic diversity in classrooms provide their students with meaningful learning experiences, which pave the road for success for children of all backgrounds. Such teachers implement what is referred to as a "culturally relevant pedagogy" (Ladson-Billings, 1994). Such a pedagogy, which is tailored to meet the needs of culturally and linguistically diverse students will enhance academic achievement, thus leads to success in school.

While there is little research evidence substantiating that linguistically and culturally diverse students learn better when their teachers are of the same ethnic and cultural background (Nieto, 1992) ${ }^{1}$, recruiting minorities into teacher education programs has been offered as a potential solution (Au \& Blake, 2003; Johnson \& Miller, 2002). Further, Sleeter (2001) suggests closing the achievement gap by (a) preparing all teachers for working with students of diverse backgrounds and (b) recruiting teachers from diverse backgrounds. Although the minority background of a teacher does not mean that the teacher is effective and successful in teaching diverse students, some factors are certainly beneficial: such teachers are likely to empathize with the students; they serve as role models; and, in most cases, they reside in the community and know the realities of students' lives; therefore, they can draw connections between academic content and 
students' prior knowledge, making this content more meaningful (LadsonBillings, 1994). Other research studies have also acquiesced that there is value in recruiting teacher candidates who have shared the school experiences of their students (see, for example, Au \& Blake, 2003; Haberman, 1996). In the Canadian setting, recruiting teachers of diverse backgrounds into teacher education programs is one essential means of meshing the ideals of the original Multiculturalism Policy (1971) with the reality of twenty-first century, multicultural Canada.

\section{Understanding Windsor and the Teacher Candidates}

For the past three years (since 2004), in the teacher education program at the Faculty of Education, University of Windsor, we have offered a Language and Cultural Engagement Seminar. In its second year, this noncredit seminar started with about 70 participants out of whom 40 stayed throughout the year. While in the beginning the group of students consisted of teacher candidates from minority backgrounds and some mainstream Canadian, the latter gradually faded away; consequently, the seminar ended with all students being either recent immigrants ${ }^{2}$ (mainly from the geographical regions of South and East Asia, former Soviet Union, North Africa, Middle East, and South America) or Canadians born from minority cultures. Many of the immigrant candidates already had previous teaching experiences and were looking to become accredited to teach in Ontario. All of them had obtained at least one university degree in their countries of origin. The diversity of these students, though a small percentage in the University of Windsor's overall teacher education program, mimics the general settlement patterns of the city of Windsor.

A Canadian border city located directly south of Detroit, Michigan, Windsor has a population of about 300,000 and has been identified as the fastest growing city in Ontario, after Toronto (Statistics Canada, 2005). Windsor has also been identified as the third most common settlement site in the province of Ontario, and, in the period since 1996, has experienced the largest percentage increase in visible minority residence in Ontario (People for Education, 2005). Importantly for our discussion here, is that Windsor's racial diversity is often compared with that of Detroit, a city with a well documented history of racial conflict that climaxed with the race riots of 1943 and 1967, and initiated the socalled 'white flight' to the suburbs (Fasenfest, Booza, \& Metzger, 2004; Sugrue, 1995). In the local region, historical narratives of slaves escaping to Canada and settling around Windsor play a key role in Canadian self-definitions as a sanctuary from American slavery and racial discrimination, a notion that oversimplifies the complexity of the lived experience of Black immigrants, both then and now (Walcott, 2003). Another narrative that is commonly used to demonstrate the local region's discourse of tolerance and racial harmony as a distinguishing feature of Windsor vis-à-vis Detroit's race relations is of how firefighters, police officers and other citizens of Windsor protected the safety and property of Detroit homeowners during the race riots of 1967. 
This border location and comparison with Detroit are important for our discussion in that they act to mask the discourses of racism and prejudice, consequently making it difficult for teacher candidates to have their concerns and experiences around these issues seriously addressed. The predominantly mainstream teaching population, for instance, considers acts of racism inconsequential or trivial as this is something that is generally associated with "across the border."

\section{The Seminar}

The seminar was initiated based on observations that some teacher candidates, the majority of whom from minority cultures, had difficulties in the program, especially within the practice teaching component. Reports from the then program coordinator revealed that some teacher associates would refuse to host a teacher candidate once they realized that $\mathrm{s} / \mathrm{he}$ was from a minority culture, and that this occurred even in cases when the associate had originally agreed to accept the candidate. In many instances, associate teachers would use language as the underlying reason for their decision. For instance, they would state that they feared that students would not understand the teacher candidate's teaching because of accent, which would result in a waste of teaching time as the teacher would have to "re-teach" lessons that the candidate would have taught. Evidence also exists indicating that there have been teacher candidates who were pulled out of teaching practice placements because of irreconcilable differences emanating from cultural and linguistic based tensions. In such instances, the teacher candidate would be offered an alternative placement, usually with an associate teacher reputable for cultural understanding. There were also reports of unfair treatment of these candidates such as unmerited practicum evaluations and derogatory cultural and/or racist comments. The teacher candidates often shared some of these experiences with those professors they felt were culturally close and therefore sympathetic to their situations. These factors, together with our interest in issues of diversity and social justice, inspired us to design a seminar that would help mainly internationally educated teacher candidates deal with nuances of language and culture in Canadian schools so that they would be better prepared for their teaching practice. The teacher education program is 36 weeks long with 12 weeks devoted to teaching practice, organized in four blocks.

The seminar was organized around six key components: video taping of candidates' mock teaching accompanied with feedback from the instructors and public school personnel; school visits to observe classes and become familiarized with the environment; de-briefing after each teaching practice block; discussions around language and culture in the Canadian context; and second language instruction. At the end of the seminar, teacher candidates received certificates for successfully participating in the course, which were considered important for job application portfolios. Participants in the seminar responded to three questionnaires that were strategically placed at the beginning, middle and end of the program. We used responses to each set of questionnaires to reflect and inform our practice. Since we obtained permission to use data collected in the last 
questionnaire only, all other data were treated as anecdotal and were used herein to achieve triangulation of data in support of the themes. In retrospect, we started this seminar out of needs of praxis hoping that we will be able to advance theory as well.

\section{In Pursuit of Being Canadian}

Table 1 is a summary of reflective needs analysis gathered at the beginning of the seminar through discussions and a questionnaire as is typical in ethnographic and narrative methodologies.

Table 1: Summary of Articulated Needs

\begin{tabular}{|c|c|c|}
\hline \multicolumn{3}{|c|}{ Teacher Candidates Needed Help with: } \\
\hline Language & $\begin{array}{c}\text { Classroom } \\
\text { Management / Issues } \\
\text { of Practice }\end{array}$ & Cultural Issues \\
\hline $\begin{array}{l}\text { Spoken English: Accent; } \\
\text { pronunciation by native } \\
\text { speakers. } \\
\text { Written English: Grammar; } \\
\text { spelling; Canadian English. } \\
\text { Presentations and public } \\
\text { speech: Speaking clearly } \\
\text { and slowly by exaggerating } \\
\text { the words; teacher voice. } \\
\text { Classroom discourse: } \\
\text { Questioning and answering } \\
\text { techniques. }\end{array}$ & $\begin{array}{l}\text { Classroom Management: } \\
\text { Disciplining students } \\
\text { ("punishment, rewards, } \\
\text { detention, yelling"); } \\
\text { behavioral cases (what to } \\
\text { say and do); managing a } \\
\text { split class; special-needs } \\
\text { students; bored students. } \\
\text { Issues of practice: "What to } \\
\text { do if some students try to } \\
\text { make fun of my slightly } \\
\text { different accent?"; avoiding } \\
\text { confrontation with } \\
\text { associate teacher. }\end{array}$ & $\begin{array}{l}\text { School Culture in Canada: Taking } \\
\text { into account students' cultural and } \\
\text { family backgrounds; resolving } \\
\text { cultural conflicts; special holidays; } \\
\text { fun cultural activities. } \\
\text { Canadian social structure. } \\
\text { Language barriers for different } \\
\underline{\text { cultures (respectful practice). }} \\
\underline{\text { Racial discrimination and how to }} \\
\text { deal with it: "Dealing with students } \\
\text { and associate teachers that are not } \\
\text { very welcoming to non-native } \\
\text { Canadian teachers." }\end{array}$ \\
\hline
\end{tabular}

As part of the needs assessment we found that teacher candidates were preoccupied with practice; that is, with teaching as performance. They needed more:

a) opportunities to exercise language (especially verbal activities);

b) instructions on classroom management ("punishment, rewards, detention, yelling");

c) discussion around school culture in Canada ("being treated differently/with prejudice"); and,

d) specific resources for teaching. 
Very early in the seminar - before the teacher candidates went out to their first teaching practice, we organized video taping of their mock teaching in a neighboring school. The candidates were excited and highly motivated to be part of this activity, since it afforded them the opportunity to visit the school, watch themselves and others teach, and receive feedback from professors, peers, and the school teachers. Even the candidates from mainstream cultures wanted to participate in the video taping, as well as the students from traditionally nonconfrontational ("shy") cultures. Teacher candidates were anxious about being watched by the students they would teach, associate teachers, and faculty advisors, and found value in the mock teaching activity because it allowed them to first practice in a non-threatening but realistic school environment.

Since for the majority of our students, English was an additional language, we incorporated a language instruction component in the seminar (20 hours). Based on the initial needs assessment, the English as a Second Language (ESL) specialist worked with teacher candidates on pronunciation, questioning techniques, and other technical elements of school language discourse. Prior to working on language learning we organized several school visits to allow for better bonding with the ESL teacher and for observation of her work with ESL high school students. After each teaching practice we engaged in de-briefing sessions where we discussed evaluation concerns, relations with associate teachers, issues of ethnicity, justice, and power.

In May 2006, we were invited to give a presentation about the seminar at the Ministry of Education/Faculties of Education Forum in Toronto, Canada, which gave us additional opportunity to reflect and discuss issues with the larger audience of scholars, practitioners and administrators. To further facilitate collaboration as well as provide opportunity for broader engagement in our presentation, we involved two candidates from the seminar, as well as the ESL instructor.

The data collected through the students' feedback at the completion of the seminar were organized according to three major thematic arenas that had emerged as critical areas of focus throughout seminar engagements. Table 2 offers a summary of the typical comments according to these themes.

The responses to the last questionnaire informed us of the success of the seminar in engaging and addressing teacher candidates' concerns and in helping them deal with the nuances of the Canadian classroom. Through the seminar we were able to increase candidates' confidence; help them see their practices within an emerging community of learners; and confront issues of social justice in the educational environment. However, more work needed to be done in polishing teacher candidates' linguistic expressions especially with regards to the political appropriateness of language (for example, in using the term "cope with different cultures" instead of "tolerate different cultures"). 
Table 2: Course Feedback

\begin{tabular}{|c|c|c|c|}
\hline Questions & Culture & Language & Community \\
\hline $\begin{array}{l}\text { What did } \\
\text { you learn } \\
\text { about } \\
\text { yourself } \\
\text { through } \\
\text { participat- } \\
\text { ing in this } \\
\text { seminar? }\end{array}$ & $\begin{array}{l}\text { - I am not the only one who } \\
\text { is suffering; who is different. } \\
\text { - I have to do everything } \\
\text { very hard way because I } \\
\text { have an accent. I just have to } \\
\text { live with it. } \\
\text { (apathy, cynicism) } \\
\text {-I feel very confident. I am } \\
\text { motivated a lot. (agency) }\end{array}$ & $\begin{array}{l}\text { - that my language } \\
\text { skills are not as bad as } \\
\text { I had originally taught. } \\
\text { - that I should never } \\
\text { assume. I must always } \\
\text { look at the whole } \\
\text { picture and I also } \\
\text { learnt communication } \\
\text { is very important. }\end{array}$ & $\begin{array}{l}\text { - The experiences I'm } \\
\text { going through are not } \\
\text { unusual. Others had the } \\
\text { same battles. I could say } \\
\text { I fit in the group of the } \\
\text { future teachers. } \\
\text { - still a lot of things I } \\
\text { need to learn both from } \\
\text { professors and my peers. }\end{array}$ \\
\hline $\begin{array}{l}\text { What did } \\
\text { you learn } \\
\text { about your } \\
\text { peers? }\end{array}$ & $\begin{array}{l}\text {-A lot of peers have different } \\
\text { backgrounds/ from different } \\
\text { countries. It is very useful to } \\
\text { learn from them and make } \\
\text { some new friends. }\end{array}$ & $\begin{array}{l}\text { - that my peers also } \\
\text { have accents and there } \\
\text { is no embarrassment } \\
\text { for having a different } \\
\text { accent and culture. } \\
\text { - that my peers are still } \\
\text { very capable and } \\
\text { confident teachers } \\
\text { who have a voice that } \\
\text { needs to be heard. }\end{array}$ & $\begin{array}{l}\text { - peers with similar } \\
\text { background were more } \\
\text { united and helpful to } \\
\text { each other; group work } \\
\text { with native and non- } \\
\text { traditional students did } \\
\text { not work so well. } \\
\text { - to support each other. }\end{array}$ \\
\hline $\begin{array}{l}\text { What did } \\
\text { you learn } \\
\text { about your } \\
\text { teaching? }\end{array}$ & $\begin{array}{l}\text { - I just need to keep working } \\
\text { hard and nothing can stop } \\
\text { me. } \\
\text { - what is acceptable in } \\
\text { Canadian classes that is } \\
\text { different from my country. } \\
\text { - to always be sensitive to the } \\
\text { needs of students who } \\
\text { represent the fabric of } \\
\text { diversity. (agency) }\end{array}$ & $\begin{array}{l}\text { - I felt improvement in } \\
\text { my questioning } \\
\text { techniques, e.g., how } \\
\text { to address some } \\
\text { language } \\
\text { differences... }\end{array}$ & \\
\hline $\begin{array}{l}\text { What did } \\
\text { you learn } \\
\text { about } \\
\text { teaching } \\
\text { experiences } \\
\text { in the } \\
\text { seminar? }\end{array}$ & $\begin{array}{l}\text { - This program was big } \\
\text { emotional support to us to } \\
\text { deal with the pressure we } \\
\text { had. I became aware of } \\
\text { cultural \& language barriers } \\
\text { that many professionals face } \\
\text { - to listen to others' } \\
\text { comments and feelings. That } \\
\text { helps me to contribute my } \\
\text { feelings. }\end{array}$ & $\begin{array}{l}\text { - how to ask right } \\
\text { questions or express } \\
\text { my concerns about } \\
\text { different issues. }\end{array}$ & $\begin{array}{l}\text { - I heard a lot of other } \\
\text { people's points of views, } \\
\text { difficulties and success } \\
\text { stories, and the group } \\
\text { discussions brought } \\
\text { people from varied } \\
\text { backgrounds together } \\
\text { and promoted empathy } \\
\text { and understanding. }\end{array}$ \\
\hline
\end{tabular}


Throughout the seminar we recorded, discussed with each other as professors, and addressed candidates' concerns. Table 3 is a summary of the major concerns that were expressed. While in the beginning the teacher candidates expressed mostly needs and concerns, by the end of the seminar they started giving more recommendations for improvement of the overall teacher education program.

Table 3: List of Major Concerns at the End of the Year

\begin{tabular}{|c|c|c|}
\hline Early Concerns & Midway Concerns & Final Concerns \\
\hline $\begin{array}{l}\text { Language proficiency. } \\
\text { Classroom } \\
\text { management: Relation } \\
\text { with associate teacher; } \\
\text { acceptance by pupils. } \\
\text { Becoming Canadian: } \\
\text { Canadian culture. }\end{array}$ & $\begin{array}{l}\text { About students: If they } \\
\text { understand the candidate; } \\
\text { motivation level; how to } \\
\text { know them better? } \\
\text { About teacher liability. } \\
\text { Feeling powerless: } \\
\text { Relation with associate } \\
\text { teacher; respect. }\end{array}$ & $\begin{array}{l}\text { Socio-Cultural: } \\
\text { Awareness of the } \\
\text { "subtle racism taking } \\
\text { place within the } \\
\text { system"; being } \\
\text { different. Language: } \\
\text { "Living with an } \\
\text { accent." }\end{array}$ \\
\hline
\end{tabular}

\section{Discussion: Language and cultural practices, contested identities and the politics of diversity}

Filling the void

The seminar was primarily about culture and language in the context of teaching and learning within the North American milieu. Traditionally, international university students have been positioned within North American discourses as "needing help because they have 'deficiencies'; as needing to adjust and adapt and be assimilated, resulting in the loss of their voice(s)" (Koehne, 2004, p. 13). Therefore, we structured the seminar in a way that was oppositional to this 'deficiency' positioning; conversely, we were interested in encouraging, hearing and legitimizing these marginal voices, aiming at collaborative discourses that would allow for valuing of experiences, critical construction of meaning leading to healthy discussions, opportunity for active engagement, flexibility, and emerging curriculum. More importantly, we planned the seminar fully aware that many of the candidates would arrive with already nuanced understandings of the practices of teaching and learning, which they would have gained from their countries of origin (Myles et al., 2006). In this regard, we focused on themes and strategies that encouraged teacher candidates to bring in, specifically, previous cultural knowledge, use it to tabulate what they were learning and to engage their students during the teaching placements. This seminar structure supported the well known cliché that learners are not "empty vessels" waiting to be filled by teachers (Freire, 1987). It also supported Dei's (2000) notion of the need to provide learners with opportunities for creativity and resourcefulness, acknowledging that 'immigrant' does not mean 'ignorance' or 'backwardness.' 
As indicated by the two quotes below, the informal structure allowed for a flow of discussion that teacher candidates identified as unique to the seminar. Similarly, they commented on the value of hearing others' experiences:

I learnt and heard a lot of other people's points of views, difficulties, comments, and success stories, and I think the group discussions were a good method of bringing a mass of people from a varied background together and promoting empathy and understanding.

When you attend this kind of program and discuss our grievances together, we feel that they are also sailing in the same boat. We get solace when we hear others' experiences. We learn a lot from others experiences - [they] teach us a lot of things. It can warn you in advance what are the things you can face and prepare yourself well in advance.

The success of the seminar in valuing students' experiences can be located in the nature of the information that teacher candidates felt comfortable to share, that is, candidates felt that they possessed legitimate knowledge (Bourdieu, 1986) worth allotment. In this regard, the seminar was able to break the trend identified by Dei (2000) of practices that only legitimize conventional knowledge production that privileges some knowledge forms and sets up a hierarchy of knowledge. Many of the experiences teacher candidates related regarded the way they were positioned as ethnic minorities, immigrants, etc., in the university and in the schools in which they practiced, a positioning that did not always feel empowering. Teacher candidates expressed that the seminar allowed them to explore the intricacies of this positioning, as well as devise with each other ways to address it especially in their teaching practices. They felt supported, thus, positioning the seminar as a culturally-accepting space that they could use, "to learn to make problematic their view of life; search for different ways to think about themselves; challenge their self-imposed as well as institutionally defined limitations; affirm their cultural and individual strengths; and embrace the possibilities for a better world" (Darder, 1997, p. 342).

Negotiating and representing identity

Another focus for this seminar was to find ways to make teacher candidates from diverse linguistic and cultural backgrounds feel valued in the program through affirming their identities and through working with them to devise ways for tapping into their cultural identities as powerful resources for teaching. One of the ways that we used to encourage teacher candidates to see themselves as embodied subjects, that is, as with markers of identity that are structured on the oscillation of tension and privilege (Kelly, 1997), was through discussions that drew on identities of the two of us as female, immigrant, additional learners of English in the Canadian academy. Therefore, our experiences of immigration and settlement, additional language learning, learning to teach in Canadian classes, etc., were used as resources to facilitate candidates' examination of their own practices. Consequently, in the light of the knowledge they gained from our experiences, teacher candidates began to examine their own practices and to look at how their

26 Canadian and International Education Vol. 36 no.1 -June 2007 
cultural and linguistic backgrounds had shaped and continued to shape how they learn to teach, and what they do in their teaching practicum, as well as how they are perceived by those with whom they work. One teacher candidate indicated the importance of our identities to the seminar:

I like to listen to the professors' advices because they have their own experiences as immigrants. You feel that there are some connections between your own feelings and these (sic) to professors.

While teacher candidates appreciated our identities and the knowledge that these identities embodied, this did not necessarily translate into their use and the affirmation of their own cultural identities, especially in the classrooms in which they conducted their teaching practice. That is, even though as immigrant professors we used our own experiences in the seminar, there is no evidence that teacher candidates did the same in their own practicum classrooms even in their last stages of the program. Rather, they expressed practices that indicate that they were "becoming Canadian" or doing things in a Canadian way; therefore, "blending in." The following three statements from the last seminar feedback questionnaire are informative (emphasis added):

I am not as culturally different than I first thought I was. At first, thinking I was half Chinese-half German set me apart, but I realized there are so many other teachers who have much more diverse ethnic and cultural differences.

To participating [sic] in this seminar I have learned that I am not alone from different culture and I should be proud because being a new Canadian I am going to be teacher.

I have learnt that my language skills are not as bad as I had originally thought. I now feel more culturally compatible.

In addition to information gathered through questionnaires, classroom discussions also indicated teacher candidates' preoccupation with the desire to culturally resemble and do things like mainstream Canadians at the expense of their own cultures. For instance, we encouraged candidates teaching Language Arts at the primary level to give examples from their own cultures, or to bring books to their classrooms that they had brought from their countries of origin and use them during circle time. These suggestions were at the very least, ignored, and at the most, resisted as teacher candidates were concerned that their associate teachers were not welcoming to difference. ${ }^{4}$ Such discussions occurred in spite of the continued references we made to ourselves as immigrant women who did things and spoke differently from mainstream Canadians. We noticed that teacher candidates' desire to "blend in," is not coupled with, or may even contradict practices of cultural and linguistic affirmation. While it is possible that once teacher candidates from these groups enter and are fully initiated into the profession, they will become willing and aware of the expectations from parents and students to act as role models, it is not clear when this transformation occurs. 
The lack of and resistance against cultural and linguistic identity affirmation did not mean that teacher candidates were blind to the ways that schools marginally and unconstructively presented and engaged with diversity. On the contrary, teacher candidates demonstrated increased awareness of inequalities in schools where they saw not only themselves but some of their students as victims. Responses to the midyear questionnaire, designed to find out areas that candidates felt they needed assistance with and also to map out their experiences thus far, indicate that many of them felt victimized by their associate teachers because of their cultural and/or linguistic backgrounds. Additionally, many articulated the need to learn how to reach out to students from diverse backgrounds who they felt were discriminated against, had encountered cultural conflict and were disengaged in schools. Our beliefs, based on experiences in this seminar, validate the rationale presented in educational studies for recruiting more teachers from diverse ethnic/racial backgrounds into the teaching profession. Put together, these teachers are said to be more aware of inequalities in schools and more likely to express social responsibility through commitment to working for social justice. This situation is in keeping with the characteristics of power articulated by Delpit (1988), i.e., that those with power are least aware while those with less power are more aware of its existence. The realization of participants in our seminar that their cultural contributions were either ignored or resisted supports Delpit's explication of the workings of power within educational institutions: educators not in the culture of power are not listened to so their cultural insights do not become part of the curriculum.

Re-examining concerns

Our experiences in the teacher education program in general are in tune with those of other studies that have outlined various concerns inherent in teacher education.

Concern for power and authority: This concern was one of the strongest among teacher candidates and was mainly reported and discussed after the first teaching practice block by candidates, many of whom were recent immigrants, who were surprised to find out that being a teacher in Canadian schools does not grant a position of authority, power and respect among students and parents. This notion was totally absent from their previous schooling experiences. In this regard, teacher candidates articulated the importance of introducing Canadian students to some of what they considered respectful ways of communicating with adults in general, and teachers in particular, a practice typically found in candidates' mores.

Our observations on this concern to gain respect among students, parents and colleagues and credibility as professionals are similar to O'Sullivan, Stroot and Tannehill's (1989) findings and Sarason's (1990) report of a group of new teachers who had been told by their mentors that "establishing the authority and power of the teacher was absolutely essential. Although there was variation in what they were advised to do to achieve that goal, there was none in regard to the primacy of that goal" (p. 79). Apparently, teacher power is a teacher's potential to influence the attitudes, values, beliefs, and behavior of students, and is "central to how they and others judge professional competence" (Sarason, 1990, p. 80).

28 Canadian and International Education Vol. 36 no.1 -June 2007 
Similarly, Villegas and Lucas (2002), in their study of Hispanic schools, reported that new teachers were shocked at the perceived lack of respect for teachers in schools, while within the community; teachers were held in high esteem. Dlamini and Anucha's (2005) study of Intergenerational links of youth from African communities in Windsor also reports that immigrant youth from African communities express concern about the disrespectful and confrontational ways that their peers communicate with teachers. All these observations suggest that in some instances learning to teach for teacher candidates from diverse backgrounds includes learning to accept practices that may conflict with their cultures, and entails re-conceptualizing the meaning of terms such as respect as well as taken for granted positions of authority.

Communication concern: Communication was the most commonly expressed concern from the beginning to the end of the seminar; one that we used multiple resources to address, yet the one for which, at the end of the seminar, many candidates felt they could still use much support. On one level, language concerns centred around technical aspects of English, e.g., grammar, vocabulary, etc. Although all participants had been successful in the English language screening for general admission, they felt it was important to have opportunity to hone their English skills, especially verbal skills. They also wanted opportunities to learn the commonly used phrases in classrooms, which would enable them to understand classroom discourse and allow them to engage students in less formal ways. For this part of the language concern, teacher candidates received instruction from an ESL specialist, who also provided them opportunity to visit her ESL high school classroom. These concerns would be considered small "d" discourse concerns, to use Gee's (2005) terminology, whereas the second level of communication concerns would fall under "Big D" Discourse.

This second level of the communication concern had to do with teacher candidates' perceptions of their own ways of speaking (accent, pronunciation) as different from, and therefore "inferior" to those of mainstream Canadians. The view of a non-standard accent as deficient was reported in two other studies of Canadian teacher candidates of minority background (Myles et al., 2006). To address this concern, during class meetings we discussed issues of accent, pronunciation, and different varieties of English and the ways in which these were all legitimate for communicating. In addition, as professors for whom English is an additional language, our own accents and language forms became teaching tools open for examination and reflection. Nevertheless, these discussions, together with our own communicative practices, induced limited transformation in concerns of the teacher candidates as they remained convinced that the acceptance we talked about was removed from the reality of the official school discourse they encountered. In their responses to the final questionnaire they spoke of, for example, "the need to improve their accent problem." They remained anxious of their communicative patterns because they had witnessed or experienced ridicule, had been laughed at, interrupted, and corrected by associate teachers in front of their students for using wrong terms or making spelling errors, and for having 
different accents; all experiences that had led to embarrassment or humiliation. In this regard, teacher candidates made clear connections between communicative competence and issues of authority, power and respect. In their experiences, they felt powerless in the classrooms in which they were only guests (during teaching practice) since they could not conform to the standards of the already established discourse.

Gee's conceptualization of "Big D" Discourses, i.e., "socially accepted associations among ways of using language, of thinking, valuing, acting, and interacting, in the 'right' places and at the 'right' times with the 'right' objects" (2005, p. 26) is insightful to the teacher candidates' experiences in that accent was one "way" of using the language that was considered not "right." Moreover, Gee contends that recognition is the key to Discourses; that one's way of using a language must be similar enough to the dominant discourse to be recognizable: "If it is not recognizable, then you're not 'in' the Discourse" (p. 27). In this case, students' ways of using the language, i.e., their non-standard accents, meant that they were not recognized as being fully "in" the Discourse of the classroom.

Our observations of the emphasis placed on accent, together with the teaching practice experiences of teacher candidates in the seminar, support Munro's (2003) stance that similar to characteristics such as race, in Canada, language is used to identify individuals as "foreign" or "different" and often serves as basis for discrimination. Munro argues that "some people regard an accent itself as an undesirable characteristic, and negative attitudes toward L2 user speech are sometimes unintentionally promoted even by teachers and researchers" (p. 39). While studies have repeatedly demonstrated that there is no conclusive evidence of a relationship between verbal ability and teaching ability (see, for example, Andrew, Cobb, \& Giampietro, 2005), it is clear that teachers in the schools in which our teacher candidates practiced equated ESL with inability to teach. What was even more disconcerting for us was observing teacher candidates engaged in practices of symbolic domination (Bourdieu, 1986); internalizing the messages of inadequacy and thus becoming "unwitting partners in the perpetuation of linguistic hegemony" (Egbo, 2001, p. 52). In their pursuit to improve their English language skills, the teacher candidates continued to devalue the varieties of English they knew best, and this occurred despite the embodied evidence we possessed and offered, which indicates that second language acquisition after early childhood results in speech that differs from that of native speakers (Flege, Munro \& MacKay, 1995; Piper \& Cansin, 1988; Thompson, 1991). Finally, our observations necessitate that we agree with Martin-Jones and Heller (1996) that ideologies of language and education are at the heart of relations of power since they serve to mask the real sources of inequality. In multilingual Canada the language practices of schools are bound up in the legitimization of power among different speakers of English; those who use a variety not normalized in schools find themselves at the margins of school discursive practices. It is the differential positioning of speakers within schools that facilitates practices of symbolic domination resulting in continued hegemonic practices.

30 Canadian and International Education Vol. 36 no.1 -June 2007 
Socio-cultural acceptance concern: Although the most frequently cited concerns were the communication concern and concern for power and authority, there was one predominant concern that mediated and could in fact, override the effects of those two concerns. That single concern, which could overwhelm the more frequently reported concerns, was socio-cultural acceptance. Our experiences in the seminar support other studies wherein classroom management, classroom discipline, expectations and evaluations of the associate teachers, and students' response to their teaching, were among the most expressed concerns by teacher candidates. These concerns have been identified as self concerns or task concerns (Staton, 1992). Yet, teacher candidates felt that all of these concerns could be better dealt with if they were accepted by their associate teachers and students from whom they were culturally different. They expressed feeling comfortable making mistakes in the classroom, trying different pedagogies in order to see what worked best, and discussing areas of strengths and improvement with associate teachers, if they knew that they were not being negatively judged because of who they are. Contrary to studies that based the ability to establish power and authority in the classroom on teachers' content knowledge (e.g., Britzman \& Greene, 1991), our teacher candidates possessed strong subject content knowledge; however, because they felt unaccepted in the classes in which they practiced, they felt constrained in establishing power and authority. Therefore, we propose that studies of the concerns construct be broadened to include, what we have termed, the socio-cultural acceptance concern. This concern did not diminish during the seminar. We feel that more time was needed to work on the issue of cultural acceptance and that including associate teachers in the seminar could have helped decrease this concern. We are aware that candidates' concerns change as they move towards the end of the program . More research is needed to find out the best intervention and time frame in which the socio-cultural acceptance concern starts to diminish as candidates from diverse backgrounds begin to feel accepted in schools.

Our observations are also in accordance with the Au and Blake (2003) thesis that besides ethnicity, community membership is an important factor for teachers gaining insight to students' cultural identity. In retrospect, community membership - at both the Canadian school level and within the community of diverse scholars - helped us to deal with teacher candidates' issues of diversity. However, it became apparent that they themselves needed to be immersed into the current dynamics of cultural spaces in Canada in order to confidently stand for what and who they are. As Au and Blake state, the teacher education program is too short for long-lasting effects. Our work needs to be done in the communities and schools. Until the schools wholeheartedly appropriate the notion of diversity among teachers our job will have only limited value. In other words, not only preservice, but also in-service programs have to be dedicated to acceptance, equity, and social justice in support of socializing all teacher candidates into the profession without unofficially necessitating the loss of identity. ${ }^{5}$ 


\section{Reflective Notes}

During the duration of our seminar we met various challenges. Administrative challenges were related to finding time and space for meetings with the large group of students in different programs and with conflicting schedules.

Personal challenges were experienced by us as educators. We went through a series of group and one-on-one meetings with the teacher candidates that were always very emotional. We were engaged in the discourse based on equal power (as this was a non-credit seminar, there was no evaluation component) where teacher candidates could speak freely about any issues and concerns related to the preparation of candidates from diverse backgrounds for teaching in the Canadian school system. We felt that through us the candidates gained voice, as we took their concerns and recommendations seriously and pursued them during our informal and formal Faculty meetings. As a result, this seminar received more recognition - scheduling problems have since been resolved and the second language instruction component of the seminar has been officially recognized as deserving a fulltime language specialist in the faculty. (Prior to this, the language specialist was a part time instructor with a full time position in a neighboring high school).

After the seminar was over, we had a sense of accomplishment in attending to relationships between language-culture-learning-teaching and helping candidates to examine their attitudes toward other ethno-cultural groups (including mainstream). However, we feel that we had moderate success in helping participants to develop a clearer sense of their own ethnic and cultural identities, as they predominantly wanted to blend in. Significant changes that we noticed in teacher candidates involved making shifts from teaching as performance and self-concerns toward concerns for becoming professionals.

The experiences reported by teacher candidates during the seminar reinforce our belief in the need for greater diversity in the teaching population. Specifically, the resistance teacher candidates experienced in response to their use of non-standard varieties of English, and their unwavering desire to emulate the alleged standard Canadian English, contradict the ideals of embracing diversity within a multicultural and multilingual Canada. We have learned that celebrating diversity clearly involves the legitimization of differential accents as well as differential cultural backgrounds. Practically speaking, in order for differential accents to become "normalized" or at least recognized as legitimate in the Canadian educational setting, more people with differential uses of English need to be in positions of authority within the schools. Otherwise, these people remain outside the Discourse (Gee, 2005). With more exposure to more differential accents, that is, by hearing more teachers who speak differential varieties of English within the schools, the boundaries on what is considered recognizable and therefore legitimate, can be expanded so that fewer people remain on the periphery or, in the margins, as it were. As the teacher candidates expressed, for this to happen, i.e., to move from the ideal to the lived reality of a multicultural Canada, a level of sociocultural acceptance is required. 
Despite the diverse population in Canadian schools today, teacher education has been slow to move away from the "color-blind policy" in part because cultural diversity in the school, as in society, is complex, controversial, and politically volatile. Yet, avoidance of such concepts as racism, discrimination and unequal opportunities has the effect "of neutralizing inequality and masking unequal power relations" (Ghosh, 2002, p. 90). The Language and Cultural Engagement Seminar was effective in unmasking issues of power and inequity by providing a space wherein voices traditionally silenced were heard. Its success must also be viewed in light of another development, which was the gradual disappearance of Canadian-born teacher candidates from the seminar. We believe that multicultural education must include collaboration among all groups, including those of the traditionally defined "majority." As such, we are encouraged by the work of Solomon and Levine-Rasky (2003), who initiated cross-race dyad partnerships in pre-service teacher education in Canada, as well as Ukpokodu's (2004) implementation of a program in which teacher candidates shadowed culturally different high school students. In both cases, the "majority group" teacher candidates experienced major shifts in their beliefs and actions regarding students from minority groups, and cross-cultural friendships emerged. We applaud these initiatives, which are structured to provide integrated cultural learning opportunities.

Our concerns coincide with Ladson-Billings, who claims that: "Student teaching is such an artificial environment. It's controlled, and everybody knows it. The student teacher knows it. The cooperating teacher knows it. The kids in the class know it. The supervisor shows up and everything is a performance. It's been staged. That's just a fact of life of most student teaching"(Au, 2005-2006). This "staging" provides practice of limited value to the teacher candidates; especially to those from diverse backgrounds who are vulnerable as they feel powerless as professionals and as cultural entities. For them, our seminar provided necessary scaffolding and encouragement. Finally, we hope that our work will help others design their teacher education programs in ways that encourage stronger enrollment of candidates from diverse cultural backgrounds by taking into consideration some of the issues we raised, especially those that examine how language and cultural identity may negatively affect the overall experiences of teacher candidates in various environments in which they learn to teach.

\section{Notes:}

1. There are emerging studies constructed within Aboriginal communities, particularly in Australia and New Zealand on issues of linguistic revitalization that point to the validity of this approach.

2. Following Statistics Canada's census descriptors, recent immigrant refers to permanent resident people who have been in the country for a period of five years or less. 
3. This activity was valuable to all the students regardless of the cultural background. Later on the course became more focused on marginalized cultures as mainstream students faded away.

4. This past year one primary junior candidate in the seminar was invited by her associate teacher to wear a Sari and bindi to her teaching practice as a way of using these and other resources to teach about India. Her appearance was exoticised to the point where a picture of her was featured in the local school board's newsletter as indicative of the changing face of the teaching population. This further indicates that the teaching population in Windsor is still predominately Eurocentric, despite the changes in migration over the past twenty years.

5. Vacancies within the board are widely advertised, and special efforts are made to recruit, train, and promote members of Aboriginal and racial and ethno-cultural minority groups. Support networks exist and are endorsed by the school board to assist Aboriginal and racial and ethno-cultural minority employees to achieve full participation in employment opportunities. Yet, lack of consistency between official policy and everyday reality of schools affects the way teachers from these groups envision their overall positions in these institutions. (Ministry of Education of Ontario, Guidelines for Policy Development and Implementation 1993, available at http://www.edu.gov.on.ca/eng/document/curricul/antiraci/antire.html)

\section{References}

Andrew, M. D., Cobb, C. D., \& Giampietro, P. J. (2005). Verbal ability and teacher effectiveness. Journal of Teacher Education, 56(4), 343-354.

Au, K. H., \& Blake, K. M. (2003). Cultural identity and learning to teach in diverse community: Findings from a collective case study. Journal of Teacher Education, 54(3), 192-205.

$\mathrm{Au}$, W. (2005-06, Winter). Teacher quality: Conversations on quality (Interview with Gloria Ladson-Billings). Rethinking Schools Online, 20(2). Retrieved July 16, 2006 from:

http://www.rethinkingschools.org/archive/20_02/glor202.shtml

Banks, J. (2001). Citizenship education and diversity: Implications for teacher education. Journal of Teacher Education, 52 (1), 5-16.

Bourdieu, P. (1986). The forms of capital. In J. G. Richardson (Ed.), Handbook of theory and research for the sociology of education. (pp. 241-258). Connecticut: Greenwood Press, Inc.

Brady, A., \& Shinohara, Y. (2000). Principles and activities for a transcultural approach to additional language learning. System, 28, 305-322.

Britzman, D., \& Greene, M. (1991). Practice makes practice: A critical study of learning to teach. New York: University of New York Press. 
Canadian Heritage, Government of Canada (2005). Canada 2017--Serving Canada's multicultural population for the future. Policy Forum. Quebec: Multiculturalism Project.

Carr, W. (1995). For education: Towards critical educational inquiry. Bristol, PA: Open University Press.

Cochran-Smith, M. (1997). Knowledge, skills, and experiences for teaching culturally diverse learners: A perspective for practicing teachers. In J. J. Irvine (Ed.), Critical knowledge for diverse teachers and learners (pp. 27-87). Washington, DC: American Association of Colleges for Teacher Education.

Commins, N. L., \& Marimontes, O. B. (2006). Addressing linguistic diversity from the outset. Journal of Teacher Education, 57(3), 240-246.

Darder, A. (1997). Creating conditions for cultural democracy in the classroom. In R. D. Torres, H. Gutierrez, \& A. Darder (Eds.), Latinos and education: A critical reader (pp. 331-350). New York: Routledge.

Dei, G. J. S. (2000). African development: The relevance and implications of 'Indigenousness.' In G. J. S. Dei, B. L. Hall, \& D. G. Rosenberg (Eds.), Indigenous knowledges in global contexts (pp. 70-86). Toronto, Canada: University of Toronto Press.

Delpit, L. D. (1988). The silenced dialogue: Power and pedagogy in educating other people's children. Harvard Educational Review, 58(3), 280-298.

Dlamini, S. N., \& Anucha, U. (2005). Intergenerational links of youth from African communities in Windsor. Unpublished research project. Windsor, Ontario: University of Windsor \& SSHRC.

Dlamini, S. N. (2002). From the other side of the desk: Notes on teaching about race when racialised. Race, Ethnicity \& Education, 5(1), 51-56.

Egbo, B. (2001). Differential enunciation, mainstream language, and the education of immigrant minority students: Implications for policy and practice. Journal of Teaching and Learning, 1(2), 47-61.

Fasenfest, D., Booza, J., \& Metzger, K. (2004). Living together: A new look at racial and ethnic integration in metropolitan neighborhoods, 1990- 2000. Report to the Center on Urban and Metropolitan Policy, April 2004. Washington, DC: The Brookings Institution.

Flege, J. E., Munro, M. J., \& MacKay, I. R. A. (1995). The effect of age of second language learning on the production of English consonants, Speech Communication, 16, 1-26.

Freire, P. (1987). The importance of the act of reading. In P. Freire \& D. Macedo (Eds.), Reading the word and the world. New York: Bergin \& Garvey.

Fueyo, V., \& Bechtol, S. (1999). Those who can, teach: Reflections on teaching diverse populations. Teacher Education Quarterly, 26(3), 25-35.

Garcia, R. L. (1991). Teaching in a pluralistic society: Concepts, models, strategies $\left(2^{\text {nd }}\right.$ ed.). New York: Harper Collins Publishers.

Gee, J. P. (2005). An introduction to discourse analysis: Theory and method ( $2^{\text {nd }}$ ed.). New York: Routledge.

Geertz, C. (1973). Thick description: Toward an interpretive theory of culture. New York: Basic Books.

Education canadienne et internationale Vol. $36 \mathrm{n}^{\mathrm{o}} 1$-juin 200735 
Ghosh, R. (2002). Redefining multicultural education ( $2^{\text {nd }}$ ed.). Scarborough: Nelson Thomson Learning.

Gordon, P., Aldrich, R., \& Dean, D. (1991). Education and policy in England in the twentieth century. London, England: The Woburn Press.

Grant, N. (1997). Some problems of identity and education: A comparative examination of multicultural education. Comparative Education, 33(1), 9-28.

Haberman, M. (1996). Selecting and preparing culturally competent teachers for urban schools. In J. Sikula, T. J. Buttery, \& E. Guyton (Eds.), Handbook of research on teacher education (2nd ed.) (pp. 747-760). New York: MacMillan.

James, C. E. (2001). I've never had a black teacher before. In C. E. James \& A. Shadd (Eds.), Talking about identity encounters in race, ethnicity, and language (pp. 150-167). Toronto, Canada: Between the Lines.

James, C. E. (2004, October). Assimilation to accommodation: immigrants and the changing patterns of schooling. Education Canada, 44(4), 43-45.

Johnson, S. D., \& Miller, A. N. (2002). A cross-cultural study of immediacy, credibility, and learning in the U.S. and Kenya. Communication Education, 51(3), 280-292.

Kelly, U. (1997). Schooling desire: Literacy, cultural politics and pedagogy. NY: Taylor and Francis.

Koehne, N. (2004), November). Positioning international education and international students: Multiple discourses and discursive practices. Paper presented at the AARE Conference, Melbourne, Australia.

Kramsch, C. (1998). Language and culture. Toronto: Oxford University Press.

Krenske, L. (2002). "You're researching what?" The importance of self in ethnographic research. In Sharan B. Merriam and Associates (Eds.), Qualitative research in practice: Examples for discussion and analysis, pp 283-285. San Francisco: Jossey-Bass.

Ladson-Billings, G. (1994). The dreamkeepers: Successful teachers for African-American children. San Francisco: Jossey-Bass.

Martin-Jones, M., \& Heller, M. (1996). Introduction to the Special Issues on Education in Multilingual Settings: Discourse, Identities, and Power. Linguistics and Education, 8(2), 3-16.

Munro, M. J. (2003). A primer on accent discrimination in the Canadian context. TESL Canada Journal, 20(2), 38-51.

Myles, J., Cheng, L., \& Wang, H. (2006). Teaching in elementary school: Perceptions of foreign-trained teacher candidates on their teaching practicum. Teaching and Teacher Education, 22, 233-245.

New, C. A., \& Sleeter, C. (1993). Preservice teachers' perspectives of diverse children: Implications for teacher education. Unpublished paper, University of Wisconsin at Parkdale.

Nieto, S. (1992). Affirming diversity: The sociopolitical context of multicultural education. White Plains, NY: Longman.

O'Sullivan, M., Stroot, S. A., \& Tannehill, D. (1989). Interactive video technology in teacher education. Journal of Teacher Education, 40, 20-25.

People for Education (2005). Public education in Ontario's cities - A report. Toronto: People for Education.

36 Canadian and International Education Vol. 36 no.1 -June 2007 
Peregoy, S. E., \& Boyle, O. F. (2005). Reading, writing and learning in ESL (4 ${ }^{\text {th }}$ ed.). Toronto: Pearson Education.

Piper, T., \& Cansin, D. (1988). Factors that affect the foreign accent. Canadian Modern Language Review, 44, 334-342.

Sarason, S. B. (1990). The predictable failure of educational reform. San Francisco: Jossey-Bass.

Sleeter, C. E. (2001). Preparing teachers for culturally diverse schools: Research and the overwhelming presence of whiteness. Journal of Teacher Education, 52(2), 94106.

Solomon, R. P., \& Levine-Rasky, C. (2003). Teaching for diversity: Research to practice. Toronto: Canadian Scholars' Press.

Solomon, R. P. (2004). From rethinking to transforming teacher preparation: Contextual and collaborative approaches. Working paper presented at OTF/OADE Conference. Toronto.

Statistics Canada (2004, October). Children of immigrants: How well do they do? Education Matters. Retrieved June 10, 2006 from http://www.statcan.ca/english/freepub/81-004-XIE/200410/main.htm

Statistics Canada (2005, March 22). Study: Canada's visible minority population in 2017. The Daily. Retrieved June 10, 2006 from http://www.statcan.ca/Daily/English/050322/d050322b.htm

Staton, A. Q. (1992). Teacher and student concern and classroom power and control. In V. P. Richmond \& J. C. McCroskey (Eds.), Power in the classroom: Communication, control, and concern (pp. 159-176). New Jersey: Lawrence Erlbaum Associates, Inc.

Sugrue, B. (1995). A theory-based framework for assessing domain-specific problemsolving ability. Educational Measurement, 14, 29-36.

Thompson, I. (1991). Foreign accents revisited: The English pronunciation of Russian immigrants. Language Learning, 41, 177-204.

Ukpokodu, O. N. (2004). The impact of shadowing culturally different students on preservice teachers' disposition toward diversity. Multicultural Education, 12(2), 19-28.

Villegas, A. M., \& Lucas, T. (2002). Preparing culturally responsive teachers: Rethinking the curriculum. Journal of Teacher Education, 53(1), 20-32.

Walcott, R. (2003). Black Like Who? Toronto, Canada: Insomniac Press.

Zeichner, K. M. (1993). Educating teachers for cultural diversity. East Lansing, MI: National Center for Research on Teacher Learning.

Zeichner, K. M., \& Melnick, S. L. (1996). The role of community field experiences in preparing teachers for cultural diversity. In K. Zeichner, S. Melnick, \& M. L. Gomez (Eds.), Currents of reform in U.S. teacher education (pp. 176-196). New York: Teachers College Press. 
Correspondence concerning this article should be addressed to Dragana Martinovic, University of Windsor.

Email: dragana@uwindsor.ca

Dragana Martinovic teaches and conducts research in the areas of mathematics education, technology, and language and cultural issues in education

Sheila Windle specializes in the acquisition of English as an additional language. With a great interest in socio-cultural aspects of education, she also teaches Issues in Education as well as Academic Writing courses in the Faculty of Education.

Nombuso Dlamini's focus is on research that looks at immigrant learners in Canadian schools, gender and immigration, race, culture and identity in education, as well as issues in sociolinguistics. She teaches in the areas of language and socio-cultural issues in education. 